\title{
Multilateral Possibilities: Decolonization, Preservation and the Case of Egypt
}

\author{
William Carruthers ${ }^{1}$
}

How did the rapid growth of multilateralism and international collaboration after World War II (re-)constitute preservation practices in decolonizing countries? In order to overcome structural imbalances in international organizations like UNESCO, responses to this question have often argued that post-war preservation work reflected a neo-colonialist frame. ${ }^{2}$ I do not dispute the inequalities that UNESCO and related institutions (often continue to) embody, nor do I dispute the necessity of overcoming them. But in this paper, I am more interested in starting to understand the actions behind the production of such inequalities. Rather than taking these inequalities as natural, this understanding can provide an account of the forms of power that produced such imbalances and usefully highlight their historical contingency. As Tim Winter notes, "to label the founding of the new post-war intergovernmental landscape as merely Eurocentric or neo-imperialist would miss the important political spaces it would open up."3 In this paper, I use this observation to think through the matter of preservation work in post-war Egypt, illustrating the growth of a multilateral discourse superficially benefiting Euro-Americans concerned with the excavation and preservation of ancient antiquities and architecture. Conversely, I then demonstrate how that discourse helped to materialize novel forms of Egyptian power.

Egypt provides an excellent case study. A well-known literature frames (preservation and other) work related to ancient Egyptian remains squarely in terms of colonial-era contestation. ${ }^{4}$ Yet (how) did the history of contestation around such artifacts and architecture enable new modes of political power to become manifest there? The one substantive work dealing with this question concludes in the early 1940s, despite its author's recognition that this temporal boundary is arbitrary. ${ }^{5}$ What happened after 1945 as Britain's presence in Egypt weakened, the country's monarch, Faruq, became increasingly unpopular, and various Egyptian and regional movements promoted political change? ${ }^{6}$ Before the war, many foreigners had become concerned about their ability to continue working with ancient Egyptian remains in the country. But what happened after 1945 as events gathered pace and, ultimately, Nasser became figurehead of a revolutionary nation-state? Below, I detail Egyptian responses to the forms of multilateralism that emerged around this time in relation to excavation and preservation work on the country's ancient material culture. By doing so, I illustrate how these responses fused ancient remains with the alphabet soup of multilateralism in order to instantiate those remains as constitutive of political revolution. 


\section{Multilateralism and ancient Egyptian material culture: beginnings}

First, though, I discuss the prehistory of these responses in order to illustrate the conditions which helped to form them. After 1945, the material culture of ancient Egypt had become embedded within the growing multilateral arena. To adopt multilateralism meant taking heed of a change in the way order in the world was represented; practitioners concerned with excavating and preserving Egypt's ancient past were as likely to value this representation as others. Yet paying attention to multilateralism also meant reinforcing the unbalanced sort of governance that multilateral institutions tended to generate.

In August 1947, less than two years after the Charter of the United Nations came into being, an international group of Egyptologists gathered at the University of Copenhagen to discuss the future of a discipline many of whose members (philologists, archaeologists and architects with an interest in ancient Egyptian material culture) had been riven apart by the Second World War. ${ }^{7}$ Reflecting residual tension relating to the conflict, Germans had not been invited, but representatives came to the meeting from all of Belgium, Britain, Czechoslovakia, Denmark, Egypt, France, Holland, Poland, Sweden, Switzerland, and the United States. Their gathering resulted in the foundation of an International Association of Egyptologists (IAE). The IAE (as this initial gathering suggests) was a veritable UN of the Egyptological world. Indeed, the organization promised that Germans could gain their membership if and when Germany (at that point still one country) became accredited as a member of the fledgling UNESCO. ${ }^{8}$ Yet such conditionality also suggests that a primary purpose of the IAE was conducting "boundary work": asking questions about (and also regulating) not only who could be an Egyptologist, but also what sort of work they could conduct. $^{9}$

Much of the boundary work that occurred at Copenhagen seems innocuous. During the meeting, attendees discussed whether a new ancient Egyptian dictionary project should be started and based in Copenhagen. They also asked whether Egyptologists should publish articles outside of the discipline's established journals. Beyond such discussions, though, attendees also formed a series of regulatory committees to advance the multilateral regulation of Egyptological practice, creating familiar issues related to such governance. For instance, the IAE's steering committee was to be formed of eleven members from eleven different countries. Predictably, one representative was to be from the US, and another from the Soviet Union. Yet pointing to the way in which multilateral governance also helped to marginalize countries emerging from colonialism, only one representative was to be Egyptian: Sami 
Gabra, a (British and French trained) archaeologist from Fu'ad (now Cairo) University. ${ }^{10}$ Given a long tradition of such marginalization during Egyptology's colonial development, it is difficult not to interpret this act as much other than a use of multilateral rhetoric to perpetuate a status quo privileging foreign access to ancient Egyptian material. ${ }^{11}$ At the time, at least one Egyptian Egyptologist stated that "through ... the co-operation of scholars of all nations, Egyptology will undoubtedly prosper." ${ }^{, 2}$ But the multilateral and internationalist rhetoric that they used also acted against their influence.

The IAE, as Donald Reid has noted, was "still-born."13 But institutional failure does not mean that the sort of boundary work the IAE enacted did not live on elsewhere. Even after the Egyptian Free Officers' coup of 1952, examples exist of international collaboration around ancient Egyptian remains promoting the continued primacy of European work relating to them. The coup heralded not only the start of Nasser's rise to power, but also the first Egyptian director of the country's Antiquities Service, now renamed the Department of Antiquities. Mustafa Amer was a geographer and prehistorian who believed in scientific internationalism; many of the Egyptian staff he managed also held similar ideals. ${ }^{14}$ Particular foreign institutions with an interest in excavating in Egypt now took clear advantage of this situation, even as they also asserted the value of the work that they conducted in terms of the scientific recovery and preservation of the country's past.

For instance, in 1953, Britain's Egypt Exploration Society (EES) gained a concession to dig at the site of Saqqara "on behalf of, and in collaboration with, the Department of Antiquities." 15 This internationalist language, however, was pure rhetoric: committee minutes reveal that the work provided an excuse to continue the earlier work of the British organization's new Field Director, the archaeologist Walter Bryan Emery, who had excavated monumental tombs at the site while working for the Antiquities Service in the interwar period. Minutes also reveal that the EES' committee saw the discovery and preservation of such tombs as providing a potential means of obtaining ancient Egyptian artefacts, presumably to distribute to supporters. ${ }^{16}$ There is little doubt that Emery believed in the scientific importance of the work that he carried out. Yet there is also little doubt that he (and the institution that backed him) used the language of international collaboration to enable more cynical motives, too.

Nor was this practice limited to European institutions. During 1955 and 1956, the then-University Museum of the University of Pennsylvania (UM; now the University of Pennsylvania Museum of Archaeology and Anthropology) conducted a collaborative excavation with the Department of Antiquities at the site of Mit Rahina (ancient Memphis), 
just south of Cairo. ${ }^{17}$ To a large degree, collaboration in this case was again formulated to fit the foreign institution's plans. Despite Egyptians (including Amer) making the initial moves, the excavation (novel in purpose) was formulated along the lines of the sort of technical assistance exercise promoted under the rubric of Truman's Point Four program: a rubric that used such modernization work to embed American values in countries considered useful Cold War allies. In this instance, the UM (acting without the backing of the US government) offered to transfer archaeological skills at the same time as excavating a site most of which the Department of Antiquities was keen to return to agricultural use; the Free Officers had instigated a policy of limited land reform and redistribution, and Mit Rahina was of potential agricultural value. ${ }^{18}$ The process of working out where at Mit Rahina excavation might continue - and which parts of the site should be preserved — would (or so its Board of Managers hoped) enable the American institution to embed itself in Egypt, giving it (like the EES) the prolonged opportunity to transport excavated artefacts back to Philadelphia. Rudolf Anthes, the German-born Egyptologist who the UM placed in charge of the excavation, believed in the progressive nature of the work that his field team would carry out. But, once again, collaboration also had ulterior motives.

My concern in the remainder of this paper, however, is not in the details of such collaborative excavations per se. Instead, what interests me is the way that such international collaboration around material culture - and the growth of multilateralism in relation to the preservation of Egypt's past more generally—started to enable Egyptian authorities to channel their own political wishes. Both the programmatic technical collaboration advanced by the UM and also the much more lackadaisical collaboration of the EES failed, and failed due to the policies of the Egyptian government. To understand this process, I turn to another collaborative project involving the Department of Antiquities.

\section{Preserving ancient Nubia, multilaterally}

In late 1955, the Department published a volume entitled Report on the Monuments of Nubia Likely to be Submerged by Sudd-el-' Āli Water. The Report appeared as plans gathered pace for the construction of the new Aswan High Dam (the Sudd-el- 'Ali), which was rapidly becoming the centerpiece of Egypt's revolution. ${ }^{19}$ Within the publication's pages, a committee of upper-level Department members attempted to regulate how the ancient monuments of Egyptian Nubia could be preserved and the sort of knowledge that could be gleaned from them recorded, before the reservoir (now Lake Nasser) that would form behind 
the Dam submerged them forever. The Report (written in Arabic, English, and French) constituted the ancient past as part of the contemporary process of revolutionary environmental transformation in Nubia. Moreover, it formalized this process of transformation as multilateral, attempting to make Nubia's ancient material culture a "boundary object" around which various international interests could gather and subverting the strategy that foreign institutions had previously used. ${ }^{20}$ At the publication's beginning, a reproduction of a letter from the Egyptologist Salim Hassan, leader of the departmental committee, assured Kamal al-Din Hussein, Egypt's Minister of Education, "that Egypt . . is capable of carrying out this project." Yet Hassan also noted "the hearty welcome of the Egyptian archaeologists to the assistance of some of their foreign colleagues," stating "that if UNESCO has any intention of presenting any pecuniary, material or scientific aid to Egypt . . . we have to thank it deeply.",21

Several years later, in 1960, UNESCO launched an appeal on behalf of the Egyptian and Sudanese governments for what would become its International Campaign to Save the Monuments of Nubia. ${ }^{22}$ A recent critical article (as does much official literature) seems to suggest that this event took place almost sui generis and was, to a significant extent, the result of UNESCO's agency. ${ }^{23}$ Yet the 1955 Report begs us to rethink this interpretation: the publication makes it clear that plans for the Nubian campaign (and related attempts to make UNESCO become involved with it) were afoot long before 1960. Why, then, do these plans now seem almost forgotten? I argue that the transfer of agency to the multilateral auspices of UNESCO acted as a means (now lodged in the historiography) to conceal the way in which the Egyptian government had realized that it could start to use foreign interactions with ancient material culture in order to assert and represent its own political wishes. Constituting the Nubian campaign as a boundary object also meant constituting a novel set of power relations.

The EES and the UM may have drawn on multilateralism and the rhetoric of collaboration to work in Egypt, but now the Egyptian government used this rhetoric in an attempt not only to regulate the practices of such institutions as they carried out their work, but also to manage the country's wider political interests. The Report was one step in this process. Another step (also in 1955) involved moving beyond the publication's internationalist rhetoric and mobilizing the resources of UNESCO in order to constitute the institutional framework within which this collaboration could be managed. That year, the Centre d'Étude et de Documentation sur l'Ancienne Égypte (or CEDAE) was established. CEDAE aimed to prepare for the forthcoming Nubian work by documenting antiquities, 
archaeological sites, and ancient monuments across the region and the wider country, and was formed under the terms of the UN's Expanded Program of Technical Assistance. The agency resulted, then, from an official request made by Egypt's Ministry of Education to UNESCO. And in a government memo establishing CEDAE's formal basis within Egypt, Kamal al-Din Hussein emphasized the work that such a multilateral strategy could do for the country's revolutionary future.

Writing in April 1955, the Minister stated that CEDAE could be "a source for equipping them [Egyptians] with the history of human civilization," confirming that Egypt constituted an example of a "universal civilization" ("haḍ̂ara 'älamiyya") and thereby utilizing the sort of language promoted under UNESCO's auspices. ${ }^{24}$ But at the same time as using this language, Hussein also drew on contemporary rhetoric dealing with the reform of the Egyptian peasantry in order to stress that the institution could be "a means of educating sons of the country." ${ }^{25}$ Furthermore, Hussein specified that a major rationale for CEDAE's establishment centered on concerns that "many antiquities were exported outside Egypt without registration." ${ }^{26}$ CEDAE had a revolutionary ordering mission, which the Arabic version of the agency's name made clear: the Markaz Tasjil al-Athar al-Misriyya was the Centre for Registering (tasjīl) Egyptian Antiquities. Placing work relating to Egyptian antiquities within the multilateral realm could help to constitute Egyptian property and population, ancient and modern, whether in Nubia or more widely.

Of course, this strategy came with conditions. Like other collaborative work, the foundation of CEDAE constituted expertise relating to Egypt's (now universal) civilization as linked to an institutional world outside the country. The agreement establishing the Centre stated that CEDAE was founded "in light of recommendations in the report by the head of the UNESCO mission of experts" that had studied the initial Egyptian proposal. That mission head was the Egyptologist Christiane Desroches Noblecourt of the Louvre, and her recommendations included not only working practices, but also matters relating to "employees and an appropriate budget." ${ }^{27}$ Yet even as Noblecourt headed CEDAE, this situation created opportunities for Egypt: the directives of the UN Program allowed that Egyptian officials become involved with carrying out work at the agency, too.

More than other collaborative work taking place in the country, CEDAE therefore gave Egyptians a hand as their government pushed for foreign institutions to undertake excavation and preservation work in Nubia: the agency constituted Egypt's past as a universal civilization, but to do so, it required accession to local demands as a matter of (almost moral) course. ${ }^{28}$ Retiring from the leadership of the Department of Antiquities, Amer 
became CEDAE's Egyptian director. ${ }^{29}$ Years later, Noblecourt reminisced that her work with CEDAE meant that "je fis la connaissance du professeur Mustafa Amer, dont la courtoisie et l'intelligence me sédusirent." She also complimented Amer for his work in the Department of Antiquities, which she said that he had "insuffler un sang neuf [infused with a fresh blood], inspire par les experiences les plus modernes." ${ }^{30}$ Noblecourt of course represented her dealings with Amer in this way: she wanted to suggest that their cooperation had been driven by a shared, internationalist belief in progress (which, to an extent, was true). Yet by acknowledging Amer's influence, her statement also confirms the leverage that Egyptian officials enjoyed as their work became embroiled within multilateral discourse. As the Department of Antiquities continued to push for international collaboration in Nubia, these conditions meant that it would be difficult to ignore its requests. To do otherwise would be to undermine the apparently benign cultural cooperation that such conditions promoted.

\section{Making multilateralism stick}

Unfortunately for them, foreign institutions working in Egypt often ignored these conditions. The UM's work at Mit Rahina provides a case in point. During the excavation's second season in 1956, Anthes wrote to the institution's director, Froelich Rainey, and informed him of Amer's forthcoming move to CEDAE. He noted that "although I should no means recommend striking after a close connection ... it seems to be wise to be present at work when the Center fully develops. ${ }^{, 31}$ In Egypt, Anthes could see the course that events relating to antiquities were taking. But back in Philadelphia, no one listened to his advice, and the result was a clash with an emboldened Department of Antiquities. Multilateralism mattered.

A distinct lack of success at Mit Rahina constituted the grounds for this clash. Excavating the site meant dealing with a confusing assortment of waterlogged architectural remains, and the planned transfer of archaeological skills there had failed, sunk in the site's murky depths. Moreover, excavating this complex ancient settlement (a difficult process that was itself out of the ordinary in Egypt) did not yield the sort of ancient artefacts that the UM wanted to acquire. Acting unilaterally, the institution - and in particular its Board - therefore decided to end the collaborative excavations at the site: at first postponing a planned third season of work (using the 1956 Suez conflict and its aftermath as an excuse), but then cancelling it altogether. ${ }^{32}$ The Board agreed that the funds set aside for the work could be utilized to excavate elsewhere in the country "at some future date." ${ }^{, 33}$ But this outcomeparticularly in terms of the UM's desire to choose the location of such an excavation- did 
not arise, because the Department of Antiquities now decided to call the shots. If the UM chose to adopt multilateral rhetoric, the Department would force the institution to stick to that rhetoric or face the consequences. And in a climate of Cold War paranoia and revolutionary posturing, those consequences caused no small amount of concern.

After Suez, a Polish archaeological mission had started excavating the mound of Tell Atrib, located just outside the Nile Delta city of Benha. While not excavating in the Department's preferred location of Nubia, these representatives of the Warsaw Pact still looked magnanimous as they dug: in September 1957, the (government-produced) Egypt Travel Magazine, distributed worldwide, made clear that excavations at the site (a series of settlement layers in the Nile's cultivation) fit well with the sort of work that Egypt now promoted through an agency like CEDAE. The excavations overcame the issue that "on cultivated lands the mounds are a nuisance and are steadily cut into. Hunters for antiques do further damage." Now these mounds and the antiquities within them were registered and regulated, allowing the Magazine to claim that apart from Tell Atrib "no continuously inhabited town site from ancient Egypt has ever been properly excavated," despite the site's distinct similarity to Mit Rahina. ${ }^{34}$ This apparent Polish success caused deep disquiet. For example, the Newsletter of the American Research Center in Egypt noted that the Polish work had come about "as part of the cultural exchange between Egypt and Communist countries" and that "the [Egyptian] government is extending to them many courtesies and privileges." Worse still, these courtesies included artefacts: "at the end of last year's excavation at Benha, the Polish Expedition was permitted to take back to Poland a share of the finds it has made." 35 Reacting to this situation, Helen Wall, a member of the UM's Mit Rahina team, told Anthes that if western countries did not "fill that cultural vacuum," then "the Egyptians will be forced to take people from the Russian zone." 36

The Department of Antiquities exploited this paranoia. Even before Rainey had written to the Department to cancel the Mit Rahina work, he reported that "he had received a letter from the Egyptian Government cancelling the Museum's contract to work at Memphis. They have requested us to work at Nubia [sic]." ${ }^{, 37}$ Echoing the Department's earlier Report, this letter, sent in October 1957, enclosed a list of Nubian sites, making clear that the UM could relocate its work only to these locations. The UM could either excavate in Nubia or forget about excavating in Egypt at all, leaving the country (and the future of its revolution) to archaeologists like the Poles. ${ }^{38}$ Meanwhile, other institutions also received the Department's letter; the EES' concerned committee concluded that "there was ... no promising site among those listed." ${ }^{39}$ The Department appeared to have engineered a fait 
accompli. Representing multilateral collaboration around ancient Egyptian material culture as taking the form of a benign boundary object allowed the Department to direct where excavation would occur, and perhaps even how. As Egypt asserted revolution, potential spaces of excavation - and the sorts of material held within them - played a meaningful role.

\section{Conclusion and discussion}

In post-war Egypt, making use of multilateral discourse relating to the excavation and preservation of ancient material culture allowed the country to assert its revolutionary wishes using (the promise of) interactions with the monuments and antiquities that that material culture comprised. The events detailed above only represent the start of this story. Despite the ultimatum that the Department of Antiquities presented to foreign institutions in 1957, the wholesale undertaking of archaeological work in Nubia remained uncertain, and only became a reality when UNESCO advanced its involvement beyond CEDAE to back a wider Nubian campaign. Egypt had to push the practice of multilateralism further than it perhaps wanted to. I do not have space to detail that process here. But the discussion above suggests that multilateralism ultimately made for uncomfortable archaeological bedfellows in Nubia, despite the internationalist rhetoric now attached to the eventual campaign there.

This situation prompts two thoughts. First, we need to re-examine what we think we know about the Nubian campaign. Little critical analysis has been directed toward the Nubian work, and the campaign is generally interpreted as a rare (preservationist) monument to internationalism in an otherwise heated political context. To what extent, then, was the utopia of the Nubian campaign a reality if, prior to its commencement, Egypt used multilateralism as a boundary object to assert itself in the face of the cynical use of such rhetoric by others?

Only in-depth study will tell. Secondly, we also need to pry open the foundation myth attached to the Nubian work: that impetus for the creation of the 1972 World Heritage Convention to a great extent derived from the carrying out of the campaign there. ${ }^{40}$ Given events outlined above, (how) did countries reach agreement about the Convention at the same time as they played political games with each other? To what extent did World Heritage constitute a further boundary object to neutralize political battles around preservation and related fields? Given the events that I outline above, only a nuanced understanding of the Nubian campaign will enable us to answer this question. 
${ }^{1}$ This paper is based on PhD research undertaken in the Department of History and Philosophy of Science at the
University of Cambridge, and supported by grants from the UK Arts and Humanities Research Council, Darwin College (University of Cambridge), the German Academic Exchange Service, the H. M. Chadwick Fund

(University of Cambridge), and the Royal Historical Society. Thanks to Walter Armbrust, Eleanor Robson, Jim Secord, Simon Schaffer, and Tim Winter for their help.

${ }^{2}$ See e.g. Susan Wright, "The Politicization of 'Culture,"” Anthropology Today 14 (1998): 7-15.

${ }^{3}$ Tim Winter, "Heritage Diplomacy," International Journal of Heritage Studies 21 (2015): 1002; for these political spaces as they developed in relation to UNESCO, see Lynn Meskell, "UNESCO's World Heritage Convention at 40: Challenging the Economic and Political Order of International Heritage Conservation," Current Anthropology 54 (2013): 483-94.

${ }^{4}$ Elliott Colla, Conflicted Antiquities: Egyptology, Egyptomania, Egyptian Modernity (Durham, NC: Duke University Press, 2007); Donald Malcolm Reid, Whose Pharaohs? Archaeology, Museums, and Egyptian National Identity from Napoleon to World War I (Berkeley: University of California Press, 2002).

${ }^{5}$ Colla, Conflicted Antiquities, 275-76.

${ }^{6}$ For the best overview of this political process, see Joel Gordon, Nasser's Blessed Movement: Egypt's Free Officers and the July Revolution (New York: Oxford University Press, 1992).

${ }^{7}$ Stephen Quirke, Hidden Hands: Egyptian Workforces in Petrie Excavation Archives, 1880-1924 (London: Duckworth, 2010), 4, discusses the complexity of defining Egyptology.

${ }^{8}$ Herbert Ricke to Rudolf Anthes, Uvo Hölscher, and Alexander Scharff, 30 August 1947, file 001, Rudolf Anthes Teilnachlass, Archiv der Staatlichen Museen zu Berlin.

${ }^{9}$ For boundary work, see Thomas F. Gieryn, "Boundary-Work and the Demarcation of Science from NonScience: Strains and Interests in Professional Ideologies of Scientists," American Sociological Review 48 (1983): 781-95.

${ }^{10}$ Supra note 8.

${ }^{11}$ Reid, Whose Pharaohs?, explores this marginalization in detail.

${ }^{12}$ Mustafa el-Amir, "The Birth and Growth of Egyptology," The Bulletin Issued by the Egyptian Education Bureau 40 (1949): 21. El-Amir was an Egyptologist specialized in Demotic texts.

${ }^{13}$ Donald Malcolm Reid, "Nationalizing the Pharaonic Past: Egyptology, Imperialism, and Egyptian Nationalism, 1922-1952," in Rethinking Nationalism in the Arab Middle East, ed. Israel Gershoni and James Jankowski (New York: Columbia University Press, 1997), 147.

${ }^{14}$ For Amer, see Omnia El Shakry, The Great Social Laboratory: Subjects of Knowledge in Colonial and Postcolonial Egypt (Stanford: Stanford University Press, 2007), 68.

${ }^{15}$ Walter Bryan Emery, Excavations at Sakkara: Great Tombs of the First Dynasty II (London: Egypt Exploration Society and Oxford University Press, 1954), vii.

${ }^{16}$ Minutes of the Egypt Exploration Society Executive Committee, 19 May 1954, Egypt Exploration Society Committee Minutes volume for 1942-1955, Egypt Exploration Society Lucy Gura Archive, London.

${ }^{17}$ I explore the excavation in more detail in William Carruthers, "Grounding Ideologies: Archaeology, Decolonization and the Cold War in Egypt," in Decolonization and the Cold War: Negotiating Independence, ed. Leslie James and Elisabeth Leake (London and New York: Bloomsbury Academic, 2015), 167-82.

${ }^{18}$ For land reform and Point Four in Egypt, see Jon B. Alterman, Egypt and American Foreign Assistance, 1952-1956 (Basingstoke and New York: Palgrave, 2002).

${ }^{19}$ Maslihat al-Athar [Department of Antiquities], Report on the Monuments of Nubia Likely to be Submerged by Sudd-el- 'Ali Water (Cairo: Government Press, 1955); for the lengthy genesis of the High Dam, see Ahmad Shokr, "Hydropolitics, Economy, and the Aswan High Dam in Mid-Century Egypt," The Arab Studies Journal 17 (2009): 9-31.

${ }^{20}$ For boundary objects, see e.g. Étienne Wenger, Communities of Practice: Learning, Meaning, and Identity (Cambridge: Cambridge University Press, 1998).

${ }^{21}$ Maslihat al-Athar, Report, vii-viii.

${ }^{22}$ The construction of the Aswan High Dam would lead to the flooding of Sudanese Nubia, too.

${ }^{23}$ Paul Betts, "The Warden of World Heritage: UNESCO and the Rescue of the Nubian Monuments," Past and Present, supplement 10 (2015): 100-25.

${ }^{24}$ Memo written by Kamal al-Din Hussein, 25 April 1955, file 0081-003715, Egyptian National Archives, Cairo.

${ }^{25}$ The Nasserist regime used the Egyptian non-elite signifier of "sons of the country" (awläd al-balad; sing. ibn al-balad) to stress a positive identity for the Egyptian peasantry. For the history of this term, see Sawsan elMessiri, Ibn al-Balad: A Concept of Egyptian Identity (Leiden: E. J. Brill, 1978).

${ }^{26}$ Supra note 24. 
${ }^{27}$ Ibid.

${ }^{28}$ For the UN's Expanded Program of Technical Assistance as it took place in Egypt at this time, see Cornelis Arthur Pompe, "The United Nations in Egypt: A Survey of its Organisations-Their Background Functions and Immunities," Revue égyptienne de droit international 13 (1957): 49-62.

${ }^{29}$ Morris L. Bierbrier, Who Was Who in Egyptology, 4th ed. (London: Egypt Exploration Society, 2012), 17-18.

${ }^{30}$ Christiane Desroches Noblecourt, La grande Nubiade, ou, le parcours d'une égyptologue (Paris:

Stock/Pernoud, 1992), 125.

${ }^{31}$ Rudolf Anthes to Froelich Rainey, 9 April 1956, Mit Rahina records, box 38, folder 7, archives of the

University of Pennsylvania Museum of Archaeology and Anthropology, Philadelphia (UMA).

${ }^{32}$ For further details see supra note 17.

${ }^{33}$ Froelich Rainey to Percy Madeira, 15 October 1957, Egypt records, box 46, folder 1, UMA.

${ }^{34}$ Rowland Ellis [oddly, an American writer], "Poland Digs in Egypt," Egypt Travel Magazine, September 1957, 12-16.

${ }^{35}$ Edward Wente, "Letter [untitled]," American Research Center in Egypt, Incorporated: Newsletter 26 (1957):

${ }^{36}$ Helen Wall to Rudolf Anthes, 4 May 1957, Mit Rahina records, box 38, folder 9, UMA.

${ }^{37}$ Minutes of the University Museum Board of Managers, 10 December 1957, Minutes of the University Museum Board of Managers volume for 1953-1959, UMA.

${ }^{38}$ Moharram Kamal to Froelich Rainey, 31 October 1957, Egypt records, box 46, folder 1, UMA.

${ }^{39}$ Minutes of the Egypt Exploration Society Executive Committee, 27 March 1958, Egypt Exploration Society Committee Minutes volume for 1956-1963, Egypt Exploration Society Lucy Gura Archive, London.

${ }^{40}$ See e.g. Torgny Säve-Söderbergh, Temples and Tombs of Ancient Nubia: The International Rescue Campaign at Abu Simbel, Philae and Other Sites (London and Paris: Thames and Hudson and UNESCO, 1987). 